\title{
New Vessels after Stroke: Postischemic Neovascularization and Regeneration
}

\author{
T.G. Liman M. Endres \\ Center for Stroke Research Berlin, Charité-Universitätsmedizin Berlin, and Klinik und Poliklinik für Neurologie, \\ Charité-Universitätsmedizin Berlin, Berlin, Germany
}

\section{Key Words}

Acute ischemic stroke $\cdot$ Neovascularization $\cdot$ Endothelial progenitor cells $\cdot$ Angiogenesis $\cdot$ Regeneration

\begin{abstract}
The formation of new blood vessels after acute ischemic stroke is one of the most promising approaches to future therapies in the emerging field of stroke medicine. Angiogenesis and postnatal vasculogenesis are the underlying mechanisms of the formation of new blood vessels. Bone marrow-derived endothelial progenitor cells (EPCS) are thought to play an important role in neovascularization and during the regenerative processes after a vascular injury as well as in the maintenance of endothelial integrity. This review summarizes possible mechanisms of angiogenesis, postischemic neovascularization and regeneration with a focus on the potential role of EPCs as a risk marker and as a therapeutic target in stroke medicine.
\end{abstract}

Copyright $\odot 2012$ S. Karger AG, Basel

\section{Regeneration after Stroke - A Historical Perspective}

One of the greatest challenges of current neurology is to find ways to repair damage in the adult nervous system after irreversible neuronal cell death, such as in neurode- generative diseases and stroke and after traumatic brain injury. Regeneration occurs in most body tissues; however, the nervous system is considered to be nonregenerative. Ramon y Cajal [1] stated in the earlier part of the 20th century: 'In the adult centers the nerve paths are something fixed, ended and immutable. Everything may die, nothing may be regenerated.' This dogmatic and pessimistic conception that adult neurogenesis does not exist in humans has dominated the field of neuroscience during recent decades. However, recent discoveries in neuroscience have provided insight into possible ways in which neuronal regeneration in the central nervous system may be promoted [2].

For example, Arvidsson et al. [3] demonstrated that cell genesis in neurogenic zones like the subventricular zone and subgranular zone of the dentate gyrus is stimulated following ischemic stroke. Further experimental studies provide evidence that these neuroblasts are continuously generated up to 4 months after stroke, providing a pool of cells that may develop into mature neurons and supporting surviving neurons by releasing neurotrophic hormones and other factors [4, 5]. Additionally, new concepts for angiogenesis and postnatal vascularization of the penumbra area following ischemic stroke may be pivotal in the future development of novel therapeutic approaches, including the potential role of endothelial precursor cells as well as the important role of the vascu-

\section{KARGER \\ Fax +4161306 1234 \\ E-Mail karger@karger.ch}

www.karger.com
(C) 2012 S. Karger AG, Basel

1015-9770/12/0335-0492\$38.00/0

Accessible online at:

www.karger.com/ced
Thomas Liman, MD

Klinik und Poliklinik für Neurologie, Charité-Universitätsmedizin Berlin

Campus Mitte, Charitéplatz 1

DE-10117 Berlin (Germany)

Tel. +4930450560 102, E-Mail thomas.liman@charite.de 
lature in poststroke neurogenesis [6, 7]. However, although advances in neuroscience are the most promising in the field of regenerative medicine, a lot of progress has yet to be made to overcome the gap between expectations and reality.

\section{Angiogenesis and Vasculogenesis - The Potential Role of Endothelial Progenitor Cells}

Angiogenesis and vasculogenesis are the fundamental processes during formation of new blood vessels after vascular injury, e.g. following ischemic stroke. Angiogenesis is defined as the growth of new vessels from preexisting ones, whereas vasculogenesis is defined as the formation of new vessels by 'de novo' production of endothelial cells, e.g. differentiation of precursor cells (angioblasts) into endothelial cells [8]. Bone marrow-derived endothelial progenitor cells (EPCs) are angioblasts that are thought to play an important role in endogenous vascular repair after vascular injury and in the maintenance of endothelial integrity (fig. 1). EPCs are immature endothelial cells that share common stem/progenitor cells and hematopoietic characteristics and circulate in the peripheral blood. They are mobilized from the bone marrow after, for example, vascular injury and home to the site of neovascularization, where they differentiate into endothelial cells. This is in line with the well-known concept of 'vasculogenesis' in embryonic vascular organogenesis. Therefore, the discovery of EPCs in the peripheral blood by Asahara et al. [9] has dramatically changed our understanding of adult blood vessel formation after vascular injury. EPCs are thought to possess functional and structural characteristics of stem cells as well as of mature endothelial cells. The most widely accepted current definition is detection of coexpression of the surface markers CD34, CD133 and vascular endothelial growth factor (VEGF) receptor-2, also termed kinase insert domain receptor (KDR). The coexpression of specific surface markers like CD34, CD133 and VEGF receptor-2 characterizes a specific progenitor cell subtype at a specific maturation stage. EPC subpopulations may have different functional properties. Thus, the expression of CD34, the first marker described to define EPCs, decreases over time as EPCs differentiate towards endothelial cells [9]. Other surface markers that have been described in a variety of diseases to define subpopulations of EPCs are von Willebrand factor, CD31 (platelet endothelial cell adhesion molecule), CD62E (E-selectin), CD144 (VE-cadherin) and CXC chemokine receptor type

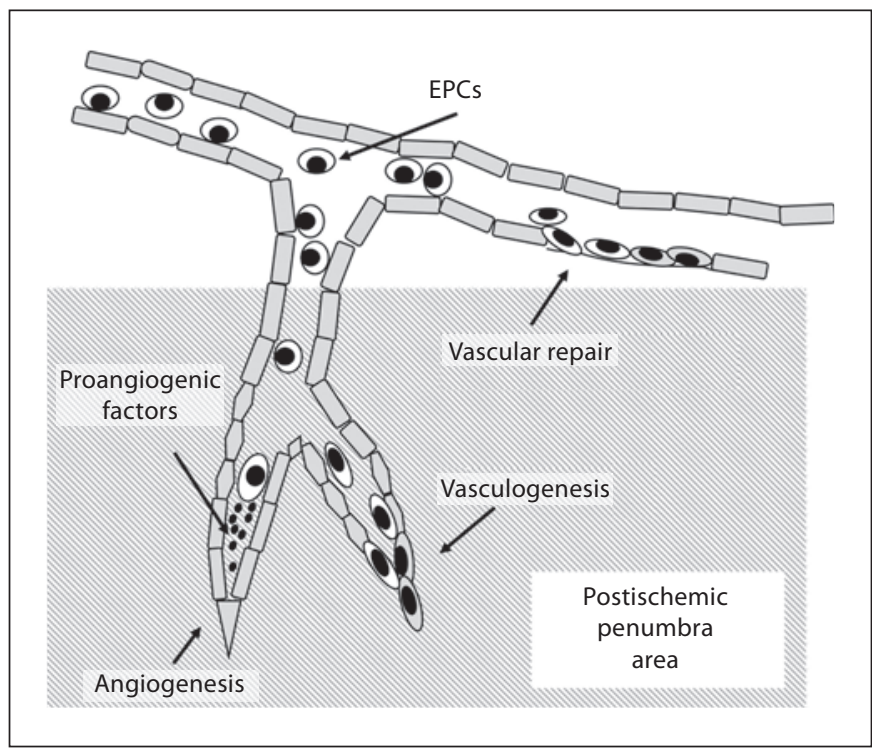

Fig. 1. Schematic representation of the potential functional role of EPCs in vascular repair, vasculogenesis and angiogenesis after cerebral ischemia.

4 (CXCR-4) [10]. However, EPCs are a heterogeneous group and many suggestions have been made to define EPCs at different maturation stages. Further research is required to understand the temporal changes and characteristics of EPC maturation.

There are two techniques to quantify EPCs, i.e. cell culture and flow cytometry. In summary, for cell culture quantification, isolated peripheral mononuclear cells are cultured for several days and form clusters that can then be counted for quantification. EPCs can be divided into two morphologically and functionally different populations, namely the 'early outgrowth EPCs', the so-called colony-forming units (CFUs) with diminished proliferation capacity and production of proangiogenic cytokines, and the 'late outgrowth EPCs' with increased proliferation capacity [11]. Secondly, EPCs can be quantified using flow cytometry, in which cells are labelled with fluorescent antibodies to the specific surface antigens of EPCs and subsequently counted with flow cytometry. The advantages of this method are that distinct subpopulations can be evaluated and that it provides the possibility of cell sorting of subpopulations (e.g. enrichment of CD34+ cells). However, EPCs are very rare in the peripheral blood, and exclusion of false-positive events can be technically difficult. Moreover, levels of EPCs in the peripheral blood differ significantly between studies depending on which method and cytometer were used. In contrast 
to flow cytometry, the culture assay provides information on EPC function and vitality, though EPCs have to be viable to respond to the culture conditions.

Activation and mobilization of EPCs from the bone marrow is induced via the production and release of EPCactivating factors, such as hypoxia-inducible factor- $1 \alpha$, estrogen, VEGF or erythropoietin, in response to peripheral tissue hypoxia such as after acute ischemic stroke or trauma [12-14]. In the periphery, stromal cell-derived factor 1 (SDF-1) mediates migration and homing of progenitor cells to the vascular endothelium through a CXCR-4 dependent mechanism $[15,16]$.

Mobilization of EPCs from the bone marrow is also dependent upon the production of nitric oxide (NO) and the local activity of matrix metalloproteinases, particularly the activity of matrix metalloproteinase-9 [17]. Subsequently, EPCs are thought to migrate and home to affected tissue like the penumbra following ischemic stroke via cytokine gradients, where they act in a paracrine fashion, leading to endothelial cell proliferation and stabilization or through transformation into endothelial cells. Several EPC-activating factors such as VEGF, SDF-1 and/ or monocyte chemotactic protein-1 are also involved in the neovascularization process of the damaged tissue, where EPCs either indirectly promote angiogenesis via paracrine mechanisms or directly contribute to the formation of new vessels from pre-existing vasculature (postnatal vasculogenesis) $[18,19]$. Importantly, our understanding of EPC physiology and their contribution to the regeneration process after vascular injury is still limited and often restricted to ex vivo EPC expansion using the cell culture methods mentioned above. Furthermore, a consensual definition and phenotypic characterization as well as standardized criteria for EPC detection using flow cytometry and cell culture assays are lacking.

\section{EPC as a Risk Marker in Vascular Diseases}

Novel biomarkers of endothelial function are an emerging field in cardiovascular research.

EPCs are thought to play a pivotal role in maintaining endothelial function and counteracting the progression of cardiovascular disease. Therefore, the levels and function of EPCs are promising surrogate markers for vascular function and cumulative cardiovascular risk. The prognostic impact of EPCs for cardiovascular risk has been investigated in several observational studies (table 1). For instance, low levels of circulating EPCs independently predict future cardiovascular events and car- diovascular death in patients with coronary heart disease [20]. In the Endothelial Progenitor Cells in Coronary Artery Disease study, the numbers of CD34+/KDR+ EPCs were measured in 519 patients (using flow cytometry) with angiographically documented coronary artery disease, and the EPC levels were correlated with cardiovascular outcomes. Multivariate analysis identified EPCs as an independent predictor of cardiovascular death, first major cardiovascular event, revascularization and hospitalization [21]. Moreover, EPC-CFU levels show a strong inverse correlation with endothelial function measured by means of flow-mediated dilatation of the brachial artery and the Framingham risk factor score [22]. In cerebrovascular diseases, research on EPCs is still limited compared to cardiovascular medicine. Taguchi et al. [23] found that higher CD34+ cell levels measured by flow cytometry in 25 patients with ischemic stroke were related to higher numbers of infarcts on MRI and cerebrovascular function as measured by the cerebral metabolic rate of oxygen and cerebral blood flow with positron emission tomography. In additional studies, they observed that in 40 stroke survivors, stroke patients with decreased levels of CD34+ cells showed significant worsening of neurologic function after 1 year, as evaluated by the rate of stroke recurrence, Barthel Index and Clinical Dementia Rating. They concluded that levels of circulating CD34+ cells have prognostic value for neural function, consistent with their potential role in maintaining the cerebral circulation $[23,24]$.

Another observational study stated that an increase in EPC levels (measured as EPC-CFUs) after acute ischemic stroke correlated with good functional outcome and reduced infarct growth [25]. Ghani et al. [26] observed decreased numbers of EPC-CFUs after acute stroke and in 'stable cerebrovascular disease' compared to healthy controls without cardiovascular risk factors. However, there are several methodological limitations to that study, e.g. healthy controls were not age-matched. In stroke patients, EPC numbers are decreased and correlate inversely with age and cardiovascular risk factors [23].

Yip et al. [27] measured CD31+CD34+, CD62E+CD34+ and CD34+KDR+ EPCs in 138 acute stroke patients, 20 healthy controls and 40 at-risk control subjects. They found that all 3 putative EPC populations were higher in stroke patients than in controls. Moreover, although lower levels of all 3 EPC populations were independently predictive of National Institute of Health Stroke Scale score $<12$ at $48 \mathrm{~h}$, only CD34+KDR+ cells were strongly correlated with neurologic improvement (National Institute of Health Stroke Scale score $\geq 4$ ) on day 21 after stroke. Re- 
Table 1. Selected observational studies investigating the role of EPCs after acute ischemic stroke and in other cerebrovascular diseases

\begin{tabular}{|c|c|c|c|c|c|c|}
\hline Study & $\begin{array}{l}\text { Journal/ } \\
\text { year }\end{array}$ & Patient population & $\begin{array}{l}\text { Outcome and } \\
\text { correlation variables }\end{array}$ & $\begin{array}{l}\text { Time points/ } \\
\text { follow-up }\end{array}$ & $\begin{array}{l}\text { Surface markers of } \\
\text { EPCs/method }\end{array}$ & Main findings \\
\hline $\begin{array}{l}\text { Taguchi } \\
\text { et al. [23] }\end{array}$ & $\begin{array}{l}\text { Circulation } \\
2004\end{array}$ & $\begin{array}{l}\mathrm{n}=25 \text { with acute } \\
\text { ischemic stroke }\end{array}$ & $\begin{array}{l}\text { course of mobilization; } \\
\text { number of infarcts; } \\
\text { CBF and } \mathrm{CMRO}_{2} \text { with } \\
\text { PET }\end{array}$ & $\begin{array}{l}\text { day } 0,3,7,14 \\
30\end{array}$ & $\begin{array}{l}\text { CD34, CD133 } \\
\text { flow cytometry }\end{array}$ & $\begin{array}{l}\text { peak of CD } 34+\text { cells on day } 7 \text {, } \\
\text { positive correlation of } \mathrm{CD} 34+\text { cells } \\
\text { with } \mathrm{CBF} \text { and } \mathrm{CMRO}_{2} \text {, negative } \\
\text { correlation with number of infarcts }\end{array}$ \\
\hline $\begin{array}{l}\text { Sobrino } \\
\text { et al. [25] }\end{array}$ & $\begin{array}{l}\text { Stroke } \\
2007\end{array}$ & $\begin{array}{l}\mathrm{n}=48 \text { with acute } \\
\text { ischemic stroke }\end{array}$ & $\begin{array}{l}\text { NIHSS score; } \\
\text { lesion growth with } \\
\text { MRI }\end{array}$ & $\begin{array}{l}\text { day } 0,7 \\
\text { mRS at day } 90\end{array}$ & $\begin{array}{l}\text { EPC-CFUs; } \\
\text { cell culture }\end{array}$ & $\begin{array}{l}\text { increase in EPCs after acute event } \\
\text { is correlated with good functional } \\
\text { outcome ( } \mathrm{mRS} \leq 2) \text { and reduced } \\
\text { infarct growth }\end{array}$ \\
\hline $\begin{array}{l}\text { Yip } \\
\text { et al. [27] }\end{array}$ & $\begin{array}{l}\text { Stroke } \\
2007\end{array}$ & $\begin{array}{l}\mathrm{n}=138 \text { with acute } \\
\text { ischemic stroke } \\
\mathrm{n}=20 \text { controls } \\
\mathrm{n}=40 \text { high risk }\end{array}$ & NIHSS score & $\begin{array}{l}\text { day } 0-2 \text {, } \\
\text { day } 21 \text {, day } 90\end{array}$ & $\begin{array}{l}\text { CD31/CD34, } \\
\text { CD62/ECD34, } \\
\text { CD34/KDR }\end{array}$ & $\begin{array}{l}\text { low EPCs are predictive of } \\
\text { NIHSS }<12 \text { at } 48 \mathrm{~h}, \mathrm{CD} 34+\mathrm{KDR}+ \\
\text { correlated with neurologic } \\
\text { improvement }(\mathrm{NIHSS} \geq 4 \text { ) at day } 21\end{array}$ \\
\hline $\begin{array}{l}\text { Rafat } \\
\text { et al. [32] }\end{array}$ & $\begin{array}{l}\text { Stroke } \\
2009\end{array}$ & $\begin{array}{l}\mathrm{n}=20 \text { with } \\
\text { moyamoya disease } \\
\mathrm{n}=15 \text { controls }\end{array}$ & levels of EPCs & - & $\begin{array}{l}\text { CD34/CD133/KDR } \\
\text { flow cytometry }\end{array}$ & $\begin{array}{l}\text { increased levels of EPCs in patients } \\
\text { with moyamoya disease compared } \\
\text { to controls }\end{array}$ \\
\hline $\begin{array}{l}\text { Pescini } \\
\text { et al. [30] }\end{array}$ & $\begin{array}{l}\text { Stroke } \\
2010\end{array}$ & $\begin{array}{l}\mathrm{n}=29 \text { with CADASIL } \\
\mathrm{n}=29 \text { controls }\end{array}$ & levels of EPCs & - & $\begin{array}{l}\text { CD34/CD133/KDR } \\
\text { flow cytometry }\end{array}$ & $\begin{array}{l}\text { lower levels of EPCs in patients } \\
\text { with CADASIL }\end{array}$ \\
\hline $\begin{array}{l}\text { Jickling } \\
\text { et al. [31] }\end{array}$ & $\begin{array}{l}\text { Stroke } \\
2009\end{array}$ & $\begin{array}{l}\mathrm{n}=172 \text { with history } \\
\text { of stroke or transient } \\
\text { ischemic attack }\end{array}$ & $\begin{array}{l}\text { counts of EPC } \\
\text { colonies; white } \\
\text { matter lesion }(\mathrm{CT})\end{array}$ & - & $\begin{array}{l}\text { CD31, vWF } \\
\text { cell culture }\end{array}$ & $\begin{array}{l}\text { EPC levels were significantly lower } \\
\text { in patients with severe age-related } \\
\text { white matter lesions }\end{array}$ \\
\hline
\end{tabular}

$\mathrm{CBF}=$ Cerebral blood flow; $\mathrm{CMRO}_{2}=$ cerebral metabolic rate of oxygen; PET = positron emission tomography; NIHSS = National Institute of Health Stroke Scale; $\mathrm{mRS}$ = modified Rankin Scale; DWI = diffusion-weighted imaging; FLAIR = fluid attenuated inversion recovery; CADASIL = cerebral autosomal dominant arteriopathy with subcortical infarcts and leukoencephalopathy; $\mathrm{vWF}=$ von Willebrand factor.

cently, Bogoslovsky et al. [28] found that EPC levels correlate with lesion volume and infarction growth in 18 patients with acute ischemic stroke. Brain imaging with 3-tesla MRI was performed on day 1 and day 5 after stroke as well as measurement of CD34+CD133+KDR+ EPC levels at baseline and on day 3. Larger lesion volumes were associated with low levels of EPCs, whereas less lesion growth was found in patients with higher EPC levels. Furthermore, they found that levels of EPCs and acute lesion volume correlate with SDF-1 $\alpha$ [29].

In cerebrovascular medicine, other recent studies demonstrated low levels of circulating EPCs in patients with cerebral autosomal dominant arteriopathy with subcortical infarcts and leukoencephalopathy [30], a correlation between low EPC levels and severe age-related white matter changes [31] and higher levels in patients with moyamoya disease [32].

Fortunately, the number of clinical studies investigating the role and impact of EPCs in cerebrovascular dis- eases is increasing; however, much remains to be understood about this promising cell lineage. Moreover, standardized measurement methods should be established and applied, i.e. to define standard values in healthy subjects.

\section{EPCs as a Therapeutic Target}

The essential role of endothelial NO synthase (eNOS) for neovascularization has been described before. Aicher et al. [33] demonstrated that eNOS expressed by bone marrow stromal cells is essential for the mobilization and functional activity of stem and progenitor cells.

Thus, low function and insufficient recruitment of EPCs after vascular injury in patients with cardiovascular risk (see above) may be due to diminished endothelial NO bioavailability and may lead to aggravation of vascular injury and diminished repair in these patients. Wer- 
ner et al. [34] demonstrated that the administration of rosuvastatin to mice with carotid artery injury leads to a delayed beneficial increase of EPC levels that promotes bone marrow-dependent re-endothelialization and diminishes vascular lesion development.

Laufs et al. [35] revealed the effect of physical activity on the production and level of EPCs via an NO-dependent mechanism in mice. These results were confirmed in patients with high vascular risk, i.e. individuals with coronary artery disease who were invited to a 4 -week training program. Exercise increases the number of EPCs in men (CD34+KDR+) and mice and also leads to an increase in neovascularization and diminished neointima formation in mice after carotid injury. Other lifestyle-related factors that have been linked to decreased EPC numbers and function are obesity, hyperlipidemia, smoking and stress. Moreover, cessation of smoking led to a rapid restoration of EPC levels after 4 weeks similar to the effects of smoking cessation on endothelial function [36].

Recently, EPC treatment/administration has been shown to improve long-term outcome in mice after transient 24-hour occlusion of the mean cerebral artery, with better performance on behavioral tests and reduced infarct volume [37]. Interestingly, blocking CXCR-4 on EPCs abolished the EPC-induced neuroprotection, supporting the hypothesis that SDF-1/CXCR-4 plays a crucial role in EPC-mediated brain protection. From clinical pilot trials in cardiovascular patients such as the Reinfusion of Enriched Progenitor Cells and Infarct Remodeling in Acute Myocardial Infarction study, evidence is emerging that EPC treatment/administration may improve vascular/cardiac function and outcome after acute myocardial infarction, for example [38]. Next to stem cell transplantation, EPCs could serve as a pharmacological target. Drugs that mobilize and functionally modify EPCs in vivo may play a major role in future therapies in cardiovascular diseases. Besides statins, several cardiovascular drugs like angiotensin-converting enzyme inhibitors, angiotensin II receptor blockers and $\beta$-blockers have demonstrated a direct beneficial effect on the mobilization and function of circulating EPCs [39]. However, a more complete understanding of the factors regulating EPC biology is essential.

\section{Angiogenesis and Stroke}

Angiogenesis is a key factor in the regeneration process in ischemic tissue. Proangiogenic therapies in stroke could lead to increased blood flow, decrease infarct size and support the restoration and recovery of neurovascular networks after ischemia. The ischemic penumbra is an area of intense restoration and active angiogenesis. Many growth factors, such as VEGF and hypoxia-inducible factor-1, are described as inducing angiogenesis and endothelial cell proliferation. This may already start as early as $12-24 \mathrm{~h}$ after stroke and persist for up to several weeks after ischemia [40].

Gertz et al. [41] were able to demonstrate the protective effect of physical exercise via induction of angiogenesis in a mild cerebral ischemia model in mice. The authors demonstrated that regulated physical activity significantly increased the number of newborn endothelial cells, upregulated eNOS in the vasculature and increased the levels of circulating EPCs. Moreover, this was associated with improved functional outcome at 4 weeks and was completely abolished when mice were treated with a NOS inhibitor or an antiangiogenic compound. Furthermore, the authors showed that running induced significantly higher densities of perfused microvessels that corresponded to a better cerebrovascular reactivity and higher absolute blood flow levels. Lastly, bone marrow chimeric mice were employed to demonstrate that bone marrow-derived cells participate in new vessel formation and are increased by physical activity [41]. In addition, there is evidence that neural precursors and angioblasts proliferate together in clusters associated with the microvasculature, lending support to the 'vascular niche' hypothesis that adult neurogenesis occurs in an angiogenic environment [42]. Most precursor cells in the subgranular zone proliferate in this environment, where neuronal, glial and endothelial precursors divide in tight clusters. These clusters can be found at a branch or terminus of small capillaries, suggesting an active process of angiogenesis.

However, poststroke blood vessel growth and its induction require a variety of complex mechanisms to form mature and functionally intact vessels. Besides morphogenesis and stabilization of angiogenic vessels, bone marrow-derived mural cells (i.e. pericytes) may be involved in blood vessel stabilization and the development of blood-brain barrier characteristics [43].

\section{Future Perspectives}

Vasculo- and angiogenesis are well studied in several fields of medicine such as oncology and ophthalmology. Antiangiogenic approaches in cancer neovascularization and retinal diseases led to approval of therapies targeting 
VEGF [44]. In stroke medicine, recent failures of several clinical trials investigating novel neuroprotective agents in acute ischemic stroke have led to some degree of pessimism and demands for a critical reappraisal in this field $[45,46]$. However, new and promising mechanisms to target neovascularization after brain ischemia and improve stroke recovery, including growth factors, adhesion molecules and progenitor cells, are emerging. The pathophysiology of ischemic brain injury is complex, and processes of endogenous repair and regeneration involving angiogenesis are dependent on the time that has elapsed since the injury. Thus, specific proangiogenic molecules have specific mechanistic functions in a defined and often limited window of time after stroke [47]. Therefore, a broad understanding of the underlying mechanisms on a cellular level is fundamental for the development of translatable angiogenic therapies that may have the potential to improve stroke outcome in future clinical trials. For example, VEGF has been shown to induce angiogenesis after intracerebroventricular injection, leading to smaller infarcts and favorable outcome in experimental stroke models $[48,49]$. Unfortunately, VEGF also leads to bloodbrain barrier leakage, inflammation and brain edema. Moreover, many other pitfalls of VEGF monotherapy have been described [47]. Thus, the optimal balance for beneficial versus detrimental effects of VEGF administration has yet to be determined.

Furthermore, biotechnology may offer a promising future perspective to improve translatable neovasculogenic approaches in stroke medicine. As already mentioned, SDF- $1 \alpha$ is one of the most potent angiogenic cytokines. SDF- $1 \alpha$ is upregulated after an ischemic event and has been shown to mobilize EPCs and induce vasculogenesis. Recently, a synthetic SDF polypeptide analog was engineered that is more efficient in inducing EPC migration, including enhanced stability and function, compared with exogenous administered SDF-1 $\alpha$ [50].
Stem cell therapeutic approaches are beyond doubt the most promising future strategies for poststroke neovascularization and regeneration. Several cell-based approaches have been proposed [51]. In 2007, Savitz et al. [52] initiated Stem Cell Therapy as an Emerging Paradigm for Stroke, which aims to facilitate the translation of cellular therapies for stroke from animal studies to clinical trials. Here, investigators from an academic background, industry, the National Institutes of Health and the Food and Drug Administration have defined guidelines (i.e. for outcome measures, cell delivery, biodistribution) and identified key translational barriers that have been experienced in prior studies and require further research. According to the Stem Cell Therapy as an Emerging Paradigm for Stroke investigators, areas that should be addressed in the future to improve and accelerate cell therapies are reliable cell labelling techniques, validated surrogate markers of stroke recovery and the development of imaging end points for clinical trials.

\section{Conclusion}

In cerebrovascular medicine, angiogenesis, postnatal vasculogenesis and vascular stem and progenitor cells may constitute novel and promising approaches for future therapies within the emerging field of neurovascular research. Notably, EPCs have the potential to change pathophysiological concepts and may serve as a future therapeutic agent as well as a novel risk marker in cerebrovascular medicine. However, even though exciting advances have been made in the field of regeneration and postischemic neovascularization, new vessel formation after stroke is a complex interplay of many factors and much remains to be understood.

\section{References}

1 Ramon y Cajal S: Degeneration and Regeneration of the Nervous System. New York, Oxford University Press, 1928.

2 Gurgo RD, Bedi KS, Nurcombe V: Current concepts in central nervous system regeneration. J Clin Neurosci 2002;9:613-617.

$\checkmark 3$ Arvidsson A, Collin T, Kirik D, Kokaia Z, Lindvall O: Neuronal replacement from endogenous precursors in the adult brain after stroke. Nat Med 2002;8:963-970.

\footnotetext{
Thored P, Arvidsson A, Cacci E, Ahlenius H, Kallur T, Darsalia V, Ekdahl CT, Kokaia Z, Lindvall O: Persistent production of neurons from adult brain stem cells during recovery after stroke. Stem Cells 2006;24:739747.

5 Wiltrout C, Lang B, Yan Y, Dempsey RJ, Vemuganti R: Repairing brain after stroke: a review on post-ischemic neurogenesis. Neurochem Int 2007;50:1028-1041.
}

6 Thored P, Wood J, Arvidsson A, Cammenga J, Kokaia Z, Lindvall O: Long-term neuroblast migration along blood vessels in an area with transient angiogenesis and increased vascularization after stroke. Stroke 2007;38: 3032-3039.

$\checkmark 7$ Eguchi M, Masuda H, Asahara T: Endothelial progenitor cells for postnatal vasculogenesis. Clin Exp Nephrol 2007;11:18-25.

-8 Risau W: Mechanisms of angiogenesis. Nature 1997;386:671-674. 
-9 Asahara T, Murohara T, Sullivan A, Silver M, van der Zee R, Li T, Witzenbichler B, Schatteman G, Isner JM: Isolation of putative progenitor endothelial cells for angiogenesis. Science 1997;275:964-967.

- 10 Sabatier F, Camoin-Jau L, Anfosso F, Sampol J, Dignat-George F: Circulating endothelial cells, microparticles and progenitors: key players towards the definition of vascular competence. J Cell Mol Med 2009;13:454471.

- 11 Hirschi KK, Ingram DA, Yoder MC: Assessing identity, phenotype, and fate of endothelial progenitor cells. Arterioscler Thromb Vasc Biol 2008;28:1584-1595.

$\checkmark 12$ Heeschen C, Aicher A, Lehmann R, Fichtlscherer S, Vasa M, Urbich C, MildnerRihm C, Martin H, Zeiher AM, Dimmeler S: Erythropoietin is a potent physiologic stimulus for endothelial progenitor cell mobilization. Blood 2003;102:1340-1346.

-13 Hoenig MR, Bianchi C, Sellke FW: Hypoxia inducible factor-1 alpha, endothelial progenitor cells, monocytes, cardiovascular risk, wound healing, cobalt and hydralazine: a unifying hypothesis. Curr Drug Targets 2008;9:422-435.

14 Iwakura A, Luedemann C, Shastry S, Hanley A, Kearney M, Aikawa R, Isner JM, Asahara T, Losordo DW: Estrogen-mediated, endothelial nitric oxide synthase-dependent mobilization of bone marrow-derived endothelial progenitor cells contributes to reendothelialization after arterial injury. Circulation 2003;108:3115-3121.

15 Zheng H, Fu G, Dai T, Huang H: Migration of endothelial progenitor cells mediated by stromal cell-derived factor-1alpha/CXCR4 via PI3K/Akt/eNOS signal transduction pathway. J Cardiovasc Pharmacol 2007;50: 274-280.

-16 Tilling L, Chowienczyk P, Clapp B: Progenitors in motion: mechanisms of mobilization of endothelial progenitor cells. Br J Clin Pharmacol 2009;68:484-492.

$\checkmark 17$ Heissig B, Hattori K, Dias S, Friedrich M, Ferris B, Hackett NR, Crystal RG, Besmer P, Lyden D, Moore MA, Werb Z, Rafii S: Recruitment of stem and progenitor cells from the bone marrow niche requires MMP-9 mediated release of kit-ligand. Cell 2002;109: 625-637.

- 18 Asahara T, Masuda H, Takahashi T, Kalka C, Pastore C, Silver M, Kearne M, Magner M, Isner JM: Bone marrow origin of endothelial progenitor cells responsible for postnatal vasculogenesis in physiological and pathological neovascularization. Circ Res 1999;85: 221-228.

19 Asahara T, Takahashi T, Masuda H, Kalka C, Chen D, Iwaguro H, Inai Y, Silver M, Isner JM: VEGF contributes to postnatal neovascularization by mobilizing bone marrow-derived endothelial progenitor cells. EMBO J 1999;18:3964-3972.

-20 Schmidt-Lucke C, Rossig L, Fichtlscherer S, Vasa M, Britten M, Kamper U, Dimmeler S,
Zeiher AM: Reduced number of circulating endothelial progenitor cells predicts future cardiovascular events: Proof of concept for the clinical importance of endogenous vascular repair. Circulation 2005;111:29812987.

21 Werner N, Kosiol S, Schiegl T, Ahlers P, Walenta K, Link A, Böhm M, Nickenig G: Circulating endothelial progenitor cells and cardiovascular outcomes. N Engl J Med 2005;353:999-1007.

22 Hill JM, Zalos G, Halcox JP, Schenke WH, Waclawiw MA, Quyyumi AA, Finkel T: Circulating endothelial progenitor cells, vascular function, and cardiovascular risk. N Engl J Med 2003;348:593-600.

23 Taguchi A, Matsuyama T, Moriwaki H, Hayashi T, Hayashida K, Nagatsuka K, Todo K, Mori K, Stern DM, Soma T, Naritomi H: Circulating cd34-positive cells provide an index of cerebrovascular function. Circulation 2004;109:2972-2975.

-24 Taguchi A, Nakagomi N, Matsuyama T, Kikuchi-Taura A, Yoshikawa H, Kasahara Y, Hirose H, Moriwaki H, Nakagomi T, Soma T, Stern DM, Naritomi H: Circulating CD34positive cells have prognostic value for neurologic function in patients with past cerebral infarction. J Cereb Blood Flow Metab 2009;29:34-38.

25 Sobrino T, Hurtado O, Moro MA, Rodriguez-Yanez $M$, Castellanos $M$, Brea $D$, Moldes O, Blanco M, Arenillas JF, Leira R, Davalos A, Lizasoain I, Castillo J: The increase of circulating endothelial progenitor cells after acute ischemic stroke is associated with good outcome. Stroke 2007;38:27592764.

26 Ghani U, Shuaib A, Salam A, Nasir A, Shuaib U, Jeerakathil T, Sher F, O'Rourke F, Nasser AM, Schwindt B, Todd K: Endothelial progenitor cells during cerebrovascular disease. Stroke 2005;36:151-153.

27 Yip HK, Chang LT, Chang WN, Lu CH, Liou CW, Lan MY, Liu JS, Youssef AA, Chang HW: Level and value of circulating endothelial progenitor cells in patients after acute ischemic stroke. Stroke 2007;39:69-74.

28 Bogoslovsky T, Chaudhry A, Latour L, Maric D, Luby M, Spatz M, Frank J, Warach S: Endothelial progenitor cells correlate with lesion volume and growth in acute stroke. Neurology 2010;75:2059-2062.

29 Bogoslovsky T, Spatz M, Chaudhry A, Maric D, Luby M, Frank J, Warach S: Stromal-derived factor-1[alpha] correlates with circulating endothelial progenitor cells and with acute lesion volume in stroke patients. Stroke 2011;42:618-625.

30 Pescini F, Cesari F, Giusti B, Sarti C, Zicari E, Bianchi S, Dotti MT, Federico A, Balestrino M, Enrico A, Gandolfo C, Gori AM, Abbate R, Pantoni L, Inzitari D: Bone marrowderived progenitor cells in cerebral autosomal dominant arteriopathy with subcortical infarcts and leukoencephalopathy. Stroke 2010;41:218-223.
31 Jickling G, Salam A, Mohammad A, Hussain MS, Scozzafava J, Nasser AM, Jeerakathil T, Shuaib A, Camicioli R: Circulating endothelial progenitor cells and age-related white matter changes. Stroke 2009;40:3191-3196.

32 Rafat N, Beck GC, Pena-Tapia PG, Schmiedek P, Vajkoczy P: Increased levels of circulating endothelial progenitor cells in patients with moyamoya disease. Stroke 2009;40: 432-438.

33 Aicher A, Heeschen C, Mildner-Rihm C, Urbich $\mathrm{C}$, Ihling $\mathrm{C}$, Technau-Ihling K, Zeiher AM, Dimmeler S: Essential role of endothelial nitric oxide synthase for mobilization of stem and progenitor cells. Nat Med 2003;9: 1370-1376.

34 Werner N, Priller J, Laufs U, Endres M, Böhm M, Dirnagl U, Nickenig G: Bone marrow-derived progenitor cells modulate vascular reendothelialization and neointimal formation: effect of 3-hydroxy-3-methylglutaryl coenzyme a reductase inhibition. Arterioscler Thromb Vasc Biol 2002;22:15671572.

35 Laufs U, Werner N, Link A, Endres M, Wassmann S, Jurgens K, Miche E, Bohm M, Nickenig G: Physical training increases endothelial progenitor cells, inhibits neointima formation, and enhances angiogenesis. Circulation 2004;109:220-226.

36 Van Craenenbroeck EM, Conraads VM: Endothelial progenitor cells in vascular health: focus on lifestyle. Microvasc Res 2010;79: 184-192.

37 Fan Y, Shen F, Frenzel T, Zhu W, Ye J, Liu J, Chen Y, Su H, Young WL, Yang GY: Endothelial progenitor cell transplantation improves long-term stroke outcome in mice. Ann Neurol 2010;67:488-497.

38 Schachinger V, Erbs S, Elsasser A, Haberbosch W, Hambrecht R, Holschermann $\mathrm{H}, \mathrm{Yu}$ J, Corti R, Mathey DG, Hamm CW, Suselbeck T, Assmus B, Tonn T, Dimmeler S, Zeiher AM: Intracoronary bone marrow-derived progenitor cells in acute myocardial infarction. N Engl J Med 2006;355:1210-1221.

-39 Antonio N, Fernandes R, Rodriguez-Losada N, Jimenez-Navarro MF, Paiva A, de Teresa Galvan E, Goncalves L, Ribeiro CF, Providencia LA: Stimulation of endothelial progenitor cells: a new putative effect of several cardiovascular drugs. Eur J Clin Pharmacol 2010;66:219-230.

40 Marti HJ, Bernaudin M, Bellail A, Schoch H, Euler M, Petit E, Risau W: Hypoxia-induced vascular endothelial growth factor expression precedes neovascularization after cerebral ischemia. Am J Pathol 2000;156:965976.

41 Gertz K, Priller J, Kronenberg G, Fink KB, Winter B, Schrock H, Ji S, Milosevic M, Harms C, Bohm M, Dirnagl U, Laufs U, Endres M: Physical activity improves long-term stroke outcome via endothelial nitric oxide synthase-dependent augmentation of neovascularization and cerebral blood flow. Circ Res 2006;99:1132-1140. 
42 Palmer TD, Willhoite AR, Gage FH: Vascular niche for adult hippocampal neurogenesis. J Comp Neurol 2000;425:479-494.

43 Kokovay E, Li L, Cunningham LA: Angiogenic recruitment of pericytes from bone marrow after stroke. J Cereb Blood Flow Metab 2006;26:545-555.

44 Potente M, Gerhardt H, Carmeliet P: Basic and therapeutic aspects of angiogenesis. Cell 2011;146:873-887.

45 Endres M, Engelhardt B, Koistinaho J, Lindvall O, Meairs S, Mohr JP, Planas A, Rothwell $\mathrm{N}$, Schwaninger M, Schwab ME, Vivien D, Wieloch T, Dirnagl U: Improving outcome after stroke: overcoming the translational roadblock. Cerebrovasc Dis 2008;25:268278.
-46 Shuaib A, Lees KR, Lyden P, Grotta J, Davalos A, Davis SM, Diener HC, Ashwood T, Wasiewski WW, Emeribe U; SAINT II Trial Investigators: NXY-059 for the treatment of acute ischemic stroke. N Engl J Med 2007; 357:562-571.

47 Navaratna D, Guo S, Arai K, Lo EH: Mechanisms and targets for angiogenic therapy after stroke. Cell Adh Migr 2009;3:216-223.

48 Sun Y, Jin K, Xie L, Childs J, Mao XO, Logvinova $A$, Greenberg DA: VEGF-induced neuroprotection, neurogenesis, and angiogenesis after focal cerebral ischemia. J Clin Invest 2003;111:1843-1851.

49 Zhang ZG, Zhang L, Jiang Q, Zhang R, Davies K, Powers C, Bruggen N, Chopp M: VEGF enhances angiogenesis and promotes blood-brain barrier leakage in the ischemic brain. J Clin Invest 2000;106:829-838.
50 Hiesinger W, Perez-Aguilar JM, Atluri P, Marotta NA, Frederick JR, Fitzpatrick JR 3rd, McCormick RC, Muenzer JR, Yang EC, Levit RD, Yuan LJ, Macarthur JW, Saven JG, Woo YJ: Computational protein design to reengineer stromal cell-derived factor-1alpha generates an effective and translatable angiogenic polypeptide analog. Circulation 2011;124:S18-S26.

51 Onteniente B, Polentes J: Regenerative medicine for stroke - are we there yet? Cerebrovasc Dis 2011;31:544-551.

52 Savitz SI, Chopp M, Deans R, Carmichael ST, Phinney D, Wechsler L: Stem Cell Therapy as an Emerging Paradigm for Stroke (STEPS) II. Stroke 2011;42:825-829. 